\title{
Regulation of UT-OC-3 ovarian carcinoma cells by cytokines: inhibitory effects on cell proliferation and activation of transcription factors AP-1 and NF- $\kappa$ B
}

\author{
Marjo Seppänen ${ }^{1,2}$, Lin $\operatorname{Lin}^{1,2}$, Juha Punnonen ${ }^{3}$, Seija Grénman ${ }^{4,5}$, Reijo Punnonen ${ }^{1}$ and Kimmo K Vihko ${ }^{1,2}$ \\ ${ }^{1}$ Department of Obstetrics and Gynecology, and ${ }^{2}$ Institute of Medical Technology, University of Tampere, Tampere, Finland, ${ }^{3}$ DNAX Research Institute, \\ Palo Alto, California, USA and Departments of ${ }^{4}$ Obstetrics and Gynecology, Turku University Central Hospital, and ${ }^{5}$ Medical Biochemistry, \\ University of Turku, Turku, Finland
}

(Correspondence should be addressed to M Seppänen, Institute of Medical Technology (IMT) and Medical School, University of Tampere, Lenkkeilijänkatu 6, FIN-33520 Tampere, Finland; +35832157 710)

\begin{abstract}
The present study was designed to investigate the growth regulatory effects of cytokines in UT-OC-3 ovarian cystadenocarcinoma cells in vitro. The effects of interleukin-6 (IL-6), interferons $\alpha$ (IFN- $\alpha$ ) and $\gamma$ (IFN- $\gamma$ ), granulocyte-macrophage colony-stimulating factor (GM-CSF), tumour necrosis factor $\alpha$ (TNF- $\alpha$ ), and transforming growth factor $\beta 1$ (TGF- $\beta 1$ ) were investigated by ${ }^{125}$ I-deoxyuridine $\left({ }^{125} \mathrm{IUdR}\right)$ incorporation assay. In order to understand better the molecular mechanisms of the observed effects, the activation of DNA-binding proteins was studied by electrophoretic mobility shift assay. In addition, cellular DNA was tested by fragmentation analysis to determine if the most growth inhibitory cytokines are able to induce programmed cell death (apoptosis). After $48 \mathrm{~h}$ in culture, TGF- $\beta 1$, TNF- $\alpha$, IFN- $\alpha$ and IL- 6 showed a clear inhibitory effect on ${ }^{125}$ IUdR incorporation $(P<0.005)$, and IFN- $\gamma$ and GM-CSF caused even more significant inhibition $(P<0.001)$. IFN- $\alpha$ and IFN- $\gamma$ were both growth inhibitory after $72 \mathrm{~h}$ in culture $(P<0.005)$. Similarly, GM-CSF induced a slight inhibition $(P<0.05)$, whereas TGF- $\beta 1$ and TNF- $\alpha$ almost blocked DNA synthesis $(P<0.001)$ after $72 \mathrm{~h}$. IL-6 had no statistically significant effect on cell proliferation after $72 \mathrm{~h}$. Transcription factors AP-1 and NF- $\kappa$ B were both constitutively expressed in UT-OC-3 cells. The binding activity of AP- 1 was found to be stimulated by the growth inhibitory cytokines, TGF- $\beta 1$ and TNF- $\alpha$, and the binding of NF- $\kappa \mathrm{B}$ was stimulated by TNF- $\alpha$. Apoptosis does not seem to be induced by any of these cytokines in the UT-OC-3 ovarian cancer cell model.
\end{abstract}

European Journal of Endocrinology 142 393-401

\section{Introduction}

The aetiology of ovarian carcinoma is unknown, but numerous studies suggest that the number of ovulations during the lifespan of a woman is critical; nulliparity, early menarche, and late menopause are all considered as risk factors $(1,2)$. The most commonly used classification of ovarian tumours was defined by the World Health Organization in 1973 (3). This classification divides the primary tumours into epithelial, sex cord-gonadal and germ cell type. Most ovarian tumours are of the epithelial type, and serous cystadenocarcinoma is the most common histological type (4).

Cytokines have a wide range of growth regulatory effects on different types of cells. Specific cytokines can directly or indirectly inhibit tumour growth and have been used in cancer therapy $(5,6)$. Furthermore, leucocytes and cytokines have been reported to have an influence on both normal and pathological ovary $(7,8)$. Leukocytes and macrophages are associated with ovarian cancer cells within solid tumour implants and ascites fluid (9-11). Better understanding of the interaction between malignant ovarian cells and immunological secretory products may help in developing novel strategies for cancer therapy.

The purpose of this study was to investigate in more detail the effects of characterized cytokines on ovarian serous cystadenocarcinoma cells in vitro.

\section{Materials and methods}

\section{Cytokines}

Recombinant human inteferon $\alpha(\operatorname{IFN}-\alpha ; 0.3-30 \mathrm{ng} / \mathrm{ml})$, IFN- $\gamma(0.3-30 \mathrm{ng} / \mathrm{ml})$, and granulocyte-macrophage colony-stimulating factor (GM-CSF; $1-100 \mathrm{ng} / \mathrm{ml}$; 
Leukomax) were all from Schering-Plough Research Institute (Kenilworth, NJ, USA). Tumour necrosis factor $\alpha$ (TNF- $\alpha ; 1-100 \mathrm{U} / \mathrm{ml})$, transforming growth factor $\beta 1$ (TGF- $\beta 1 ; 0.3-30 \mathrm{ng} / \mathrm{ml})$ and interleukin- 6 (IL-6; 3-300 U/ml) were purchased from R\&D systems (Minneapolis, MN, USA).

\section{Cell line}

The UT-OC-3 cell line has been established at the University of Turku from a primary tumour of a 60-year-old patient with well differentiated stage III ovarian serous cystadenocarcinoma $(12,13)$. Lowpassage cells were used throughout all experiments.

\section{Cell culture}

Cells were cultured in DMEM/Ham's F12 medium (Life Technologies, Gaithersburg, CA, USA) containing 10\% heat-inactivated fetal bovine serum (FBS; Gibco, Paisley, Renfrewshire, Scotland), penicillin and streptomycin (2000 U/l and $2 \mathrm{mg} / \mathrm{l}$ respectively; both from Life Technologies), L-glutamine $(2 \mathrm{mmol} / \mathrm{l}$; Life Technologies) and 1\% non-essential amino acids (Life Technologies) in $250 \mathrm{ml}$ tissue culture plates (Greiner, Frickenhausen, Germany). This supplemented medium will be referred to as basal medium throughout this article.

\section{DNA labelling}

Before the experiments, the cells were trypsinized and 20-50000 cells/well were plated on the wells of microtitre plates (Nunc, Roskilde, Denmark), and were allowed to adhere for $16 \mathrm{~h}$, followed by a 24 or $48 \mathrm{~h}$ preincubation in the presence or absence of cytokine. Subsequently, the cells were labelled with 5-( ${ }^{125}$ I-iodo $)-2^{\prime}$-deoxyuridine $\left({ }^{125} \mathrm{IUdR}\right.$; Amersham, Amersham, Bucks, UK) for $24 \mathrm{~h}$ (14). Finally, the cells were trypsinized and harvested. Incorporation of the radioactivity into cellular DNA was measured with a $\gamma$-spectrometer (1272 Clinigamma, LKB-Wallac, Turku, Finland). Dose-response analyses were performed for all inhibitory cytokines. All experiments were carried out in quadruplicate.

\section{Extraction of DNA for fragmentation analysis}

UT-OC-3 cells were cultured for 48 or $72 \mathrm{~h}$ in the presence or absence of TGF- $\beta 1$ or TNF- $\alpha$. Thereafter, $1-3 \times 10^{6}$ cells were washed and pelleted at $+4{ }^{\circ} \mathrm{C}$ $(5 \mathrm{~min}$ at $2600 \times \boldsymbol{g})$. Pellets were resuspended into $20 \mu \mathrm{l} 50 \mathrm{mmol} / \mathrm{l}$ Tris-HCl buffer (pH 8.0) containing $20 \mathrm{mmol} / \mathrm{l}$ EDTA, $0.5 \%(\mathrm{w} / \mathrm{v})$ sodium lauryl sarkosinate and $0.5 \mathrm{mg} / \mathrm{ml}$ proteinase $\mathrm{K}$ (Boehringer Mannheim, Mannheim, Germany), and incubated at $50{ }^{\circ} \mathrm{C}$ for $1 \mathrm{~h}$. Thereafter, RNase A ( $5 \mathrm{mg} / \mathrm{ml}$; Boehringer Mannheim) was added and the incubation at $50{ }^{\circ} \mathrm{C}$ was continued for an additional $1 \mathrm{~h}$. Samples were heated to $70^{\circ} \mathrm{C}$, and $10 \mu \mathrm{l} 10 \mathrm{mmol} / \mathrm{l}$ EDTA (pH 8.0) containing $1 \%$ $(\mathrm{w} / \mathrm{v})$ low-gelling-temperature agarose, $0.25 \%(\mathrm{w} / \mathrm{v})$ bromophenol blue and $40 \%(\mathrm{w} / \mathrm{v})$ sucrose were mixed with each sample before loading onto the wells of agarose gel $(1 \%)$ containing $0.1 \mathrm{mg} / \mathrm{ml}$ ethidium bromide. Electrophoresis was carried out in $800 \mathrm{mmol} / \mathrm{l}$ Tris-phosphate buffer ( $\mathrm{pH} 7.8$ ) containing $2 \mathrm{mmol} / \mathrm{l}$ EDTA at $80 \mathrm{~V}$ for $4 \mathrm{~h}$. All experiments were carried out in quadruplicate (15).

\section{Extraction of nuclear proteins}

Nuclear proteins were isolated from UT-OC-3 cells essentially as originally described by Andrews \& Faller (16). Briefly, $3 \times 10^{6}$ cells were cultured in the presence or absence of cytokine for 30, 60, 120 and 240 min; control cells were cultured in basal conditions. After culture, the cells were washed, pelleted and resuspended in $400 \mu \mathrm{l}$ cold $\left(0^{\circ} \mathrm{C}\right)$ buffer A $(10 \mathrm{mmol} / \mathrm{l} \mathrm{HEPES}-$ $\mathrm{KOH}$ (pH 7.9) containing $1.5 \mathrm{mmol} / \mathrm{l} \mathrm{MgCl}_{2}, 10 \mathrm{mmol} / \mathrm{l}$ $\mathrm{KCl}, \quad 0.5 \mathrm{mmol} / \mathrm{l}$ dithiothreitol (DTT), $0.2 \mathrm{mmol} / \mathrm{l}$ phenylmethylsulfonyl fluoride (PMSF) and $10 \mathrm{mmol} / \mathrm{l}$ aprotinin). The cells were allowed to swell on ice for $10 \mathrm{~min}$ and vortexed for $10 \mathrm{~s}$. Samples were centrifuged $(30 \mathrm{~s}$ at $15000 \times \boldsymbol{g})$ and the supernatant was discarded. The pellet was resuspended in $30 \mu \mathrm{l}$ buffer $\mathrm{C}(20 \mathrm{mmol} / \mathrm{l}$ HEPES-KOH (pH 7.9) containing $25 \%$ glycerol, $420 \mathrm{mmol} / \mathrm{l} \mathrm{NaCl}, 1.5 \mathrm{mmol} / \mathrm{l} \mathrm{MgCl}_{2}$, $0.2 \mathrm{mmol} / \mathrm{l}$ EDTA, $10 \mathrm{mmol} / \mathrm{l}$ DTT, $10 \mathrm{mmol} / \mathrm{l} \mathrm{PMSF}$ and $10 \mathrm{mmol} / \mathrm{l}$ aprotinin) and incubated on ice for $20 \mathrm{~min}$. Cellular debris was removed by centrifugation $(2 \mathrm{~min}$ at $15000 \times \boldsymbol{g})$ at $+4{ }^{\circ} \mathrm{C}$ and the supernatant fraction (containing DNA binding proteins) was stored at $-70{ }^{\circ} \mathrm{C}$.

\section{Electrophoretic mobility shift assay (EMSA)}

Nuclear protein-DNA binding reactions were carried out in a volume of $20 \mu \mathrm{l}$ containing $5 \mu \mathrm{g}$ nuclear extract protein, $10 \mathrm{mmol} / \mathrm{l}$ Tris- $\mathrm{HCl}(\mathrm{pH} 7.5), 40 \mathrm{mmol} / \mathrm{l} \mathrm{KCl}$, $1 \mathrm{mmol} / \mathrm{l}$ EDTA, $1 \mathrm{mmol} / \mathrm{l}$ DTT, $10 \%$ glycerol, $2 \mu \mathrm{g}$ poly $(\mathrm{dI}-\mathrm{dC})$ as a non-specific competitor, and $10 \mathrm{fmol}$ ${ }^{32}$ P-labelled consensus oligonucleotide probe (AP-1: $5^{\prime}$-CGC TTG ATG AGT CAG CCG GAA-3'; NF- $\kappa$ B: 5'-AGT TGA GGG GAC TTT CCC AGG C-3'). Binding reactions were performed at room temperature for $30 \mathrm{~min}$. The anti-p50, anti-p65, anti-c-jun and antic-fos antibodies were purchased from Santa Cruz Biotechnologies, Inc. (Santa Cruz, CA, USA) and used according to the manufacturer's instructions. Samples were finally analysed by electrophoresis on 4\% PAGE in $0.25 \times 22 \mathrm{mmol} / \mathrm{l}$ Tris-borate containing $22 \mathrm{mmol} / \mathrm{l}$ boric acid and $0.5 \mathrm{mmol} / \mathrm{l}$ EDTA. Gels were dried and visualized by autoradiography. The band density was quantified by a Personal Densitometer (Molecular Dynamics Inc. Sunnyvale, USA). In densitometric 
analyses, the arbitrary value (ADU) chosen for basal activity was the integral (surface area) of the specific band in the control after background calibration. All experiments were carried out in quadruplicate.

\section{Data expression and statistical analyses}

The effects of different factors on DNA synthesis of the cells cultured in the presence of cytokine were compared with the control. The results are expressed as disintegrations per minute (d.p.m.). Statistical analyses of the results were performed by paired Student's $t$-test. A $P$ value less than 0.05 was considered statistically significant.

\section{Results}

All studied cytokines had a clear growth inhibitory effect on UT-OC-3 cells, but the duration and the degree of growth inhibition varied between cytokines.

The effects of TGF- $\beta 1 \quad(5 \mathrm{ng} / \mathrm{ml})$ and TNF- $\alpha$ $(100 \mathrm{U} / \mathrm{ml})$ on UT-OC-3 cells after $48 \mathrm{~h}$ in culture are shown in Fig. 1a. TGF- $\beta 1$ induced a 2.0-fold and TNF- $\alpha$ a 1.8-fold inhibition of the incorporation of ${ }^{125} \mathrm{IUdR} \quad(P<0.005)$. IFN- $\alpha \quad(10 \mathrm{ng} / \mathrm{ml})$ and IFN- $\gamma$ $(20 \mathrm{ng} / \mathrm{ml})$ both decreased the incorporation of ${ }^{125}$ IUdR. IFN- $\alpha$ inhibited DNA synthesis 2.1-fold $(P<0.005)$, and IFN- $\gamma 3.6$-fold $(P<0.001)$ after $48 \mathrm{~h}$, respectively (Fig. 1b). A dose-dependent inhibitory effect of TNF- $\alpha$ was seen after $48 \mathrm{~h}$ in culture (Fig. 1c) at concentrations $1-100 \mathrm{U} / \mathrm{ml}$.

Figure 2 shows the effect of IFN- $\alpha(10 \mathrm{ng} / \mathrm{ml})$, IFN- $\gamma$ $(20 \mathrm{ng} / \mathrm{ml})$ TGF- $\beta(5 \mathrm{ng} / \mathrm{ml})$ and TNF- $\alpha(100 \mathrm{U} / \mathrm{ml})$ after $72 \mathrm{~h}$ in culture. IFN $\alpha$ and IFN- $\gamma$ decreased DNA synthesis 1.6 -fold and 1.9 -fold $(P<0.005)$ respectively, whereas TGF- $\beta_{1}$ and TNF- $\alpha$ almost blocked the incorporation of ${ }^{125} \mathrm{IUdR}(P<0.001)$ at this time point. The inhibitory effect of IFN- $\alpha$ was dose dependent at $72 \mathrm{~h}$ (Fig. 2b) at concentrations of $0.3-30 \mathrm{ng} / \mathrm{ml}$. A dose-response analysis was also made for TGF- $\beta$ and TNF- $\alpha$ after $72 \mathrm{~h}$, but we were not able to see a clear dose-responsiveness at this time point.

GM-CSF exerted an inhibitory time-dependent effect on ${ }^{125}$ IUdR uptake by UT-OC-3 cells: we found a 10.0fold inhibition after $48 \mathrm{~h}(P<0.001)$ and a 1.2-fold inhibition after $72 \mathrm{~h}(P<0.05)$ (Fig. 3a). Similarly, IL-6 (Fig. $3 b$ ) was able to decrease DNA synthesis by UT-OC-3 cells after $48 \mathrm{~h}$ (a 1.8-fold inhibition; $P<0.005$ ) in a dose-dependent way (Fig. $3 c$ ) at concentrations of 3$300 \mathrm{U} / \mathrm{ml}$, but no statistically significant effect was seen after $72 \mathrm{~h}$.

In order to detect apoptosis, cellular DNA was extracted after UT-OC-3 cells were cultured in the presence of TGF- $\beta 1$ and TNF- $\alpha$ for $48 \mathrm{~h}$ (data not shown) or $72 \mathrm{~h}$ (Fig. 4). The control cells were cultured in basal medium. In all experiments, the electrophoretic analyses showed intact DNA; no signs of DNA fragmentation - a feature typical of programmed cell
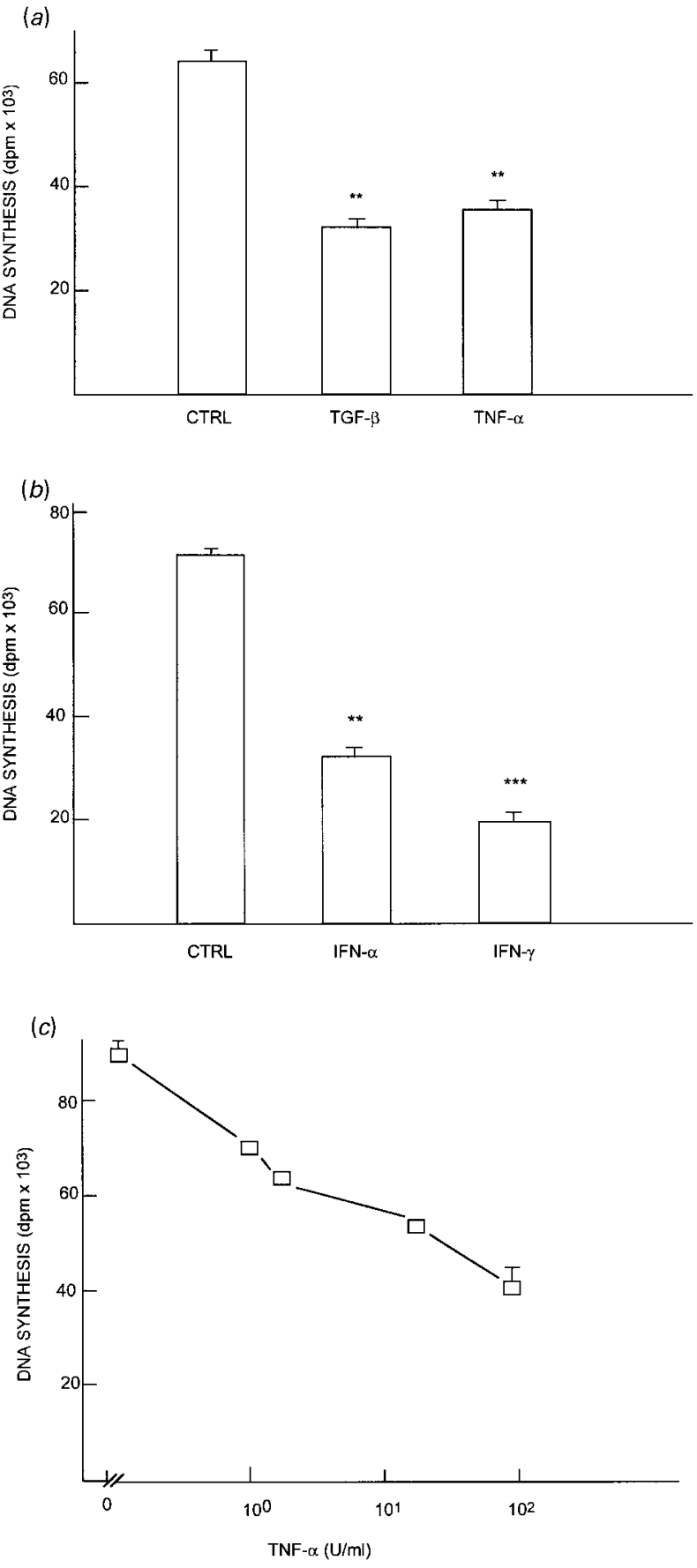

Figure 1 Effect of (a) TNF- $\alpha(100 \mathrm{U} / \mathrm{ml})$ and TGF- $\beta 1(5 \mathrm{ng} / \mathrm{ml})$ and $(b) \mathrm{IFN}-\alpha(10 \mathrm{ng} / \mathrm{ml})$ and IFN- $\gamma(20 \mathrm{ng} / \mathrm{ml})$ on DNA synthesis by UT-OC-3 cells in vitro. All cytokines showed inhibitory effects on DNA synthesis. Cells were cultured for $24 \mathrm{~h}$ in the presence or absence of cytokine and thereafter labelled with ${ }^{125} \mathrm{IUdR}$ for $24 \mathrm{~h}$. Control cells (CTRL) were cultured in medium supplemented with serum. DNA synthesis is expressed as disintegrations per minute (dpm; means \pm S.E.M.). Significant differences compared with control: ${ }^{* * *} P<0.001,{ }^{* *} P<0.005$. (c) The dose-dependent inhibitory effect of different concentrations of TNF- $\alpha$ (log scale), after $48 \mathrm{~h}$, on DNA synthesis by UT-OC-3 cells. 

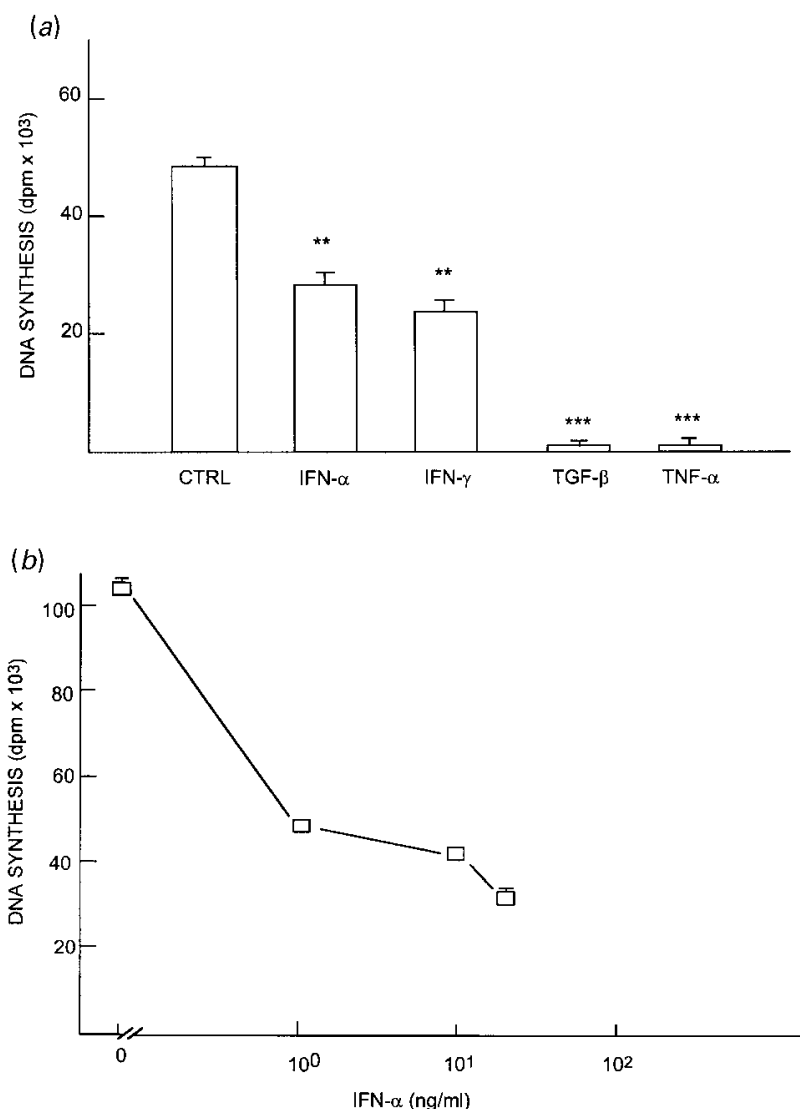

Figure 2 (a) IFN- $\alpha$ (10 ng/ml), IFN- $\gamma(20 \mathrm{ng} / \mathrm{ml})$, TGF- $\beta 1(5 \mathrm{ng} / \mathrm{ml})$ and TNF- $\alpha(100 \mathrm{U} / \mathrm{ml})$ all inhibited DNA synthesis by UT-OC-3 cells in vitro. Cells were cultured for $48 \mathrm{~h}$ in the presence or absence of cytokine and thereafter labelled with ${ }^{125} \mathrm{IUdR}$ for $24 \mathrm{~h}$. Control cells (CTRL) were cultured in medium supplemented with serum. DNA synthesis is expressed as disintegrations per minute (dpm; means \pm S.E.M.). Significant differences compared with control: ${ }^{* * *} P<0.001,{ }^{* *} P<0.005$. (b) Dose-response curve showing the inhibitory effect of IFN- $\alpha$, after $72 \mathrm{~h}$, on DNA synthesis by UT-OC-3 cells. The concentrations of the cytokine are on a log scale.

death - were observed in any of these analyses. DNA extracted from cultured mouse thymocytes served as a positive control for apoptosis throughout these studies.

As shown in Fig. 5a, the transcription factor, AP-1, was constitutively activated in UT-OC-3 ovarian carcinoma cells under basal conditions. Its binding activity was further increased by incubating the cells for 30,60, 120 and $240 \mathrm{~min}$ in the presence of the growth inhibitory cytokines, TGF- $\beta 1$ and TNF- $\alpha$. Densitometric analyses of these data indicated that the apparent amounts of the specific complexes were increased by both TGF- $\beta 1$ and TNF- $\alpha$ when compared with control (Fig. $5 b$ ).

Figure $6 a$ shows the DNA-binding activity of transcription factor, NF- $\kappa \mathrm{B}$, after $30,60,120$ and $240 \mathrm{~min}$ of incubation in the presence or absence of cytokines. Unstimulated cells showed constitutive DNA-binding of $\mathrm{NF}-\kappa \mathrm{B}$ and the binding activity was increased by
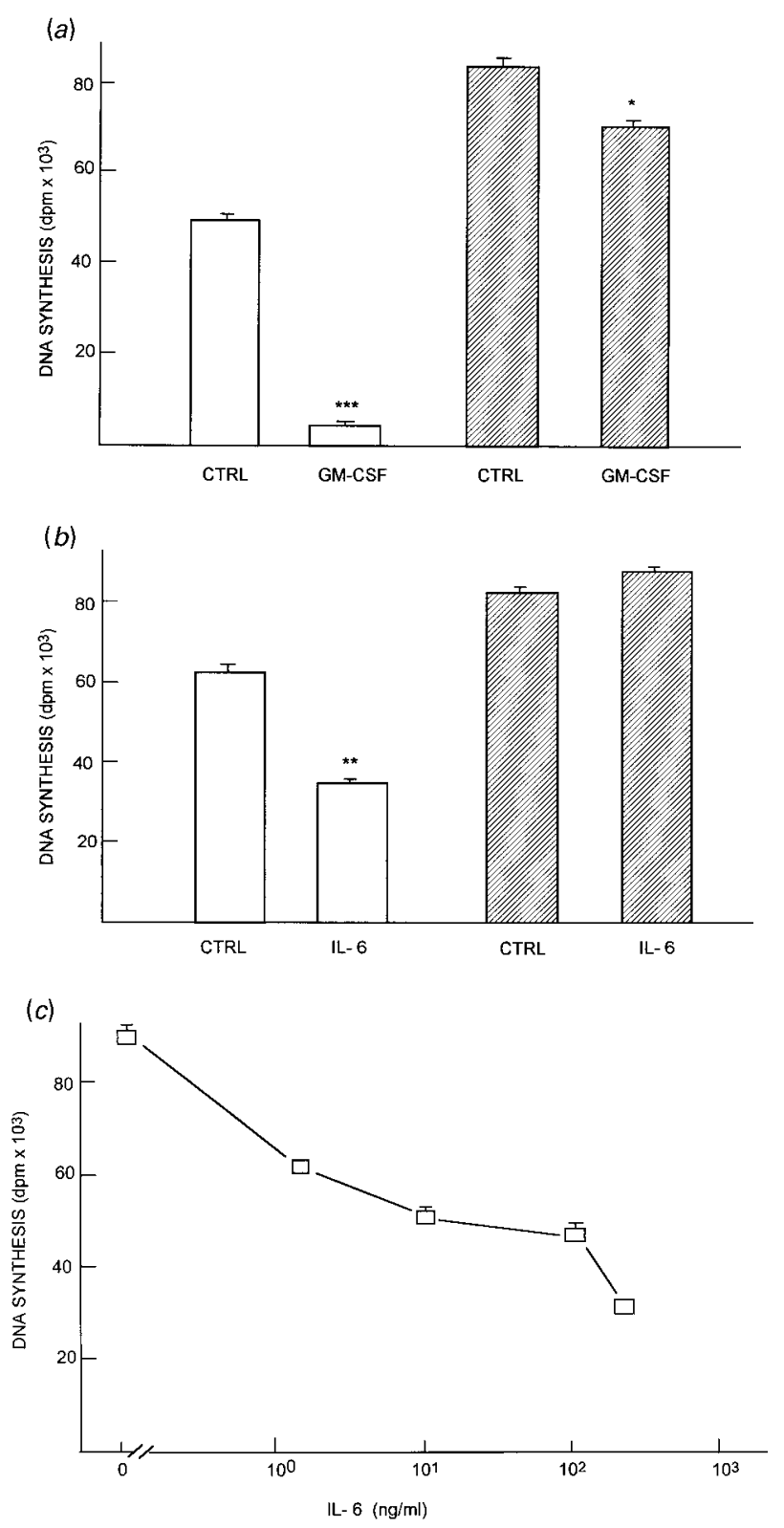

Figure 3 GM-CSF (50 ng/ml) (a) and IL-6 (100 U/ml) (b) inhibited DNA synthesis in UT-OC-3 ovarian carcinoma cells. Cells were cultured for $24 \mathrm{~h}$ (open columns) or $48 \mathrm{~h}$ (hatched columns) in the presence or absence of cytokine and thereafter labelled with ${ }^{125} \mathrm{IUdR}$ for $24 \mathrm{~h}$. Control cells (CTRL) were cultured in medium supplemented with serum. DNA synthesis is expressed as disintegrations per minute (dpm; means \pm S.E.M.). Significant differences compared with control: ${ }^{* *} P<0.001,{ }^{* *} P<0.005$, ${ }^{\star} P<0.05$. (c) The dose-dependent inhibitory effect of IL-6, after $48 \mathrm{~h}$, on DNA synthesis by UT-OC-3 cells. The concentrations of the cytokine are on a log scale.

TNF- $\alpha$ at 30, 120 and 240 min. Densitometric analyses of these data indicated that the amounts of the specific complexes were constantly increased only by TNF- $\alpha$ when compared with control (Fig. 6b). 


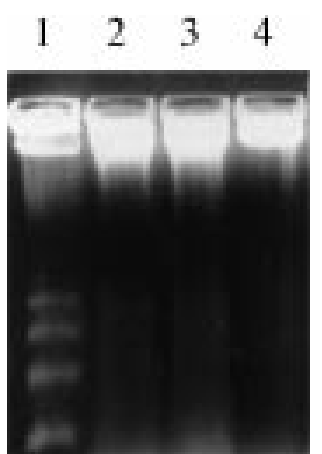

Figure 4 Electrophoretic analyses of extracted DNA isolated from UT-OC-3 human ovarian carcinoma cells. DNA fragmentation, typical of apoptosis was not observed. Lane 2, cells cultured for $72 \mathrm{~h}$ in basal conditions; lane 3 , cells cultured for $72 \mathrm{~h}$ in the presence of TGF- $\beta 1(5 \mathrm{ng} / \mathrm{ml})$; lane 4 , cells cultured for $72 \mathrm{~h}$ in the presence of TNF- $\alpha(100 \mathrm{U} / \mathrm{ml})$. Lane 1, DNA from cultured mouse thymocytes (positive control for apoptosis).

To analyse the proteins binding to the DNA, the nuclear extracts were treated with anti-p50 or antip65 (NF- $\kappa \mathrm{B})$ and anti-c-jun or anti-c-fos antibodies (AP-1) before EMSA, in order to identify components of the transcription factor-DNA-complex. Figure $7 a$ demonstrates that NF- $\kappa \mathrm{B}$ complexes present in UT-OC-3 cells were predominantly composed of p50/p65 heterodimers, as NF- $\kappa \mathrm{B}-\mathrm{DNA}$ complexes could mostly be supershifted by the antibodies. Figure $7 b$ shows the appearance of new bands associated with preincubation with AP-1-specific antibodies, but the AP-1-DNAcomplex could not be supershifted completely, suggesting that AP-1 is composed only partially by c-jun/c-fos proteins; the nature of other AP-1 complexes remains to be determined in UT-OC-3 cells.

In addition to supershift analyses, the specificity of the AP-1-DNA or NF- $\kappa \mathrm{B}-\mathrm{DNA}$ complex was confirmed by competition analyses using a 50-fold molar excess of unlabelled AP-1 or NF- $\kappa$ B oligonucleotide (data not shown).

\section{Discussion}

Cytokines are multifunctional signalling peptide molecules that have been found to interact with malignant cell growth either by direct inhibition of tumour cells or by inducing defence mechanisms of the immune system $(5,6)$. Beneficial growth inhibitory effects of cytokines have also been observed in a series of ovarian cancer cell lines $(5,17,18)$. In the present study, the growth regulatory effects of a battery of (a)

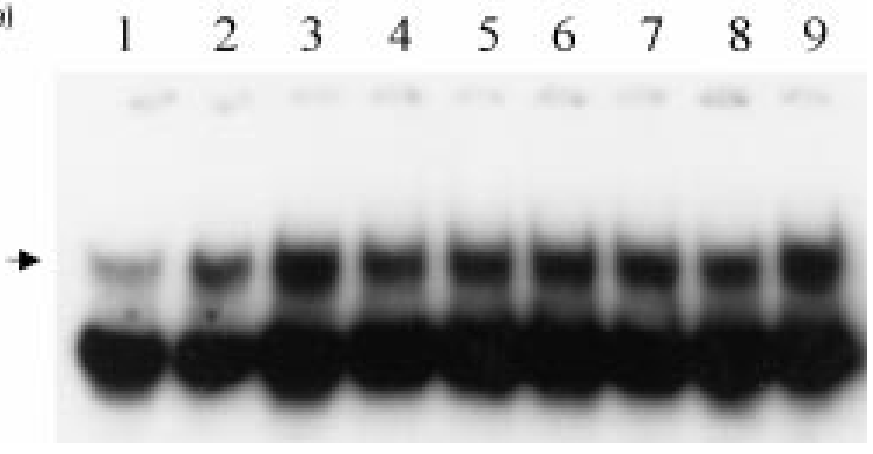

(b)

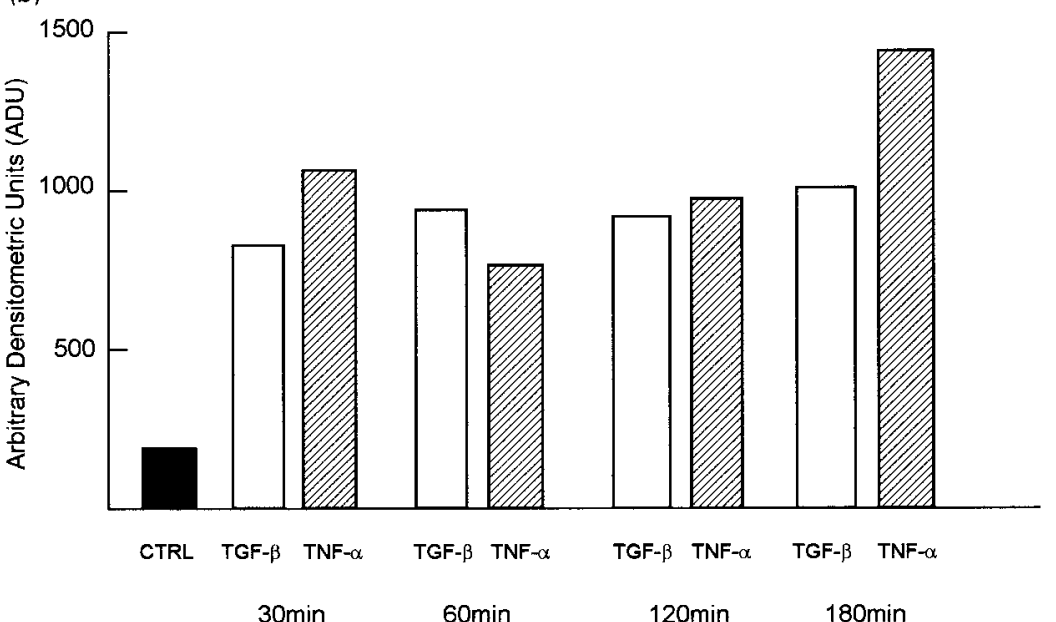

Figure 5 (a) Gel shift assay of nuclear proteins $(5 \mu \mathrm{g} /$ lane $)$ extracted from UT-OC-3 cells. AP-1 was constitutively activated (lane 1) and its binding activity was further increased by TNF- $\alpha$ and TGF- $\beta$. Cells were cultured in the presence or absence of TGF- $\beta 1$ (lane 2, $30 \mathrm{~min}$; lane 4, $60 \mathrm{~min}$; lane 6, $120 \mathrm{~min}$; lane 8, $240 \mathrm{~min}$ ) and TNF- $\alpha$ (lane 3, $30 \mathrm{~min}$; lane 5, $60 \mathrm{~min}$; lane 7, $120 \mathrm{~min}$; lane 9, $240 \mathrm{~min})$. Control cells were cultured in basal conditions (lane 1). After culture, nuclear proteins were extracted as described in the text. The binding reactions were performed at room temperature for $30 \mathrm{~min}$ whereafter the samples were analysed by PAGE. The binding reaction was carried out with a ${ }^{32} \mathrm{P}$-labelled oligonucleotide specific for AP-1. The arrow indicates transcription factor-specific bands. (b) Densitometric analyses (expressed as arbitrary densitometric units) of the effects of TGF- $\beta 1$

( $5 \mathrm{ng} / \mathrm{ml}$; open columns) and TNF- $\alpha$ $(100 \mathrm{U} / \mathrm{ml}$; hatched columns) on the activation of transcription factor AP-1 at different time points in UT-OC-3 cells (one representative experiment). AP-1 was constitutively activated and its binding activity was further increased by TNF- $\alpha$ and TGF- $\beta$. CTRL (solid column), level of constitutive binding of AP-1. 

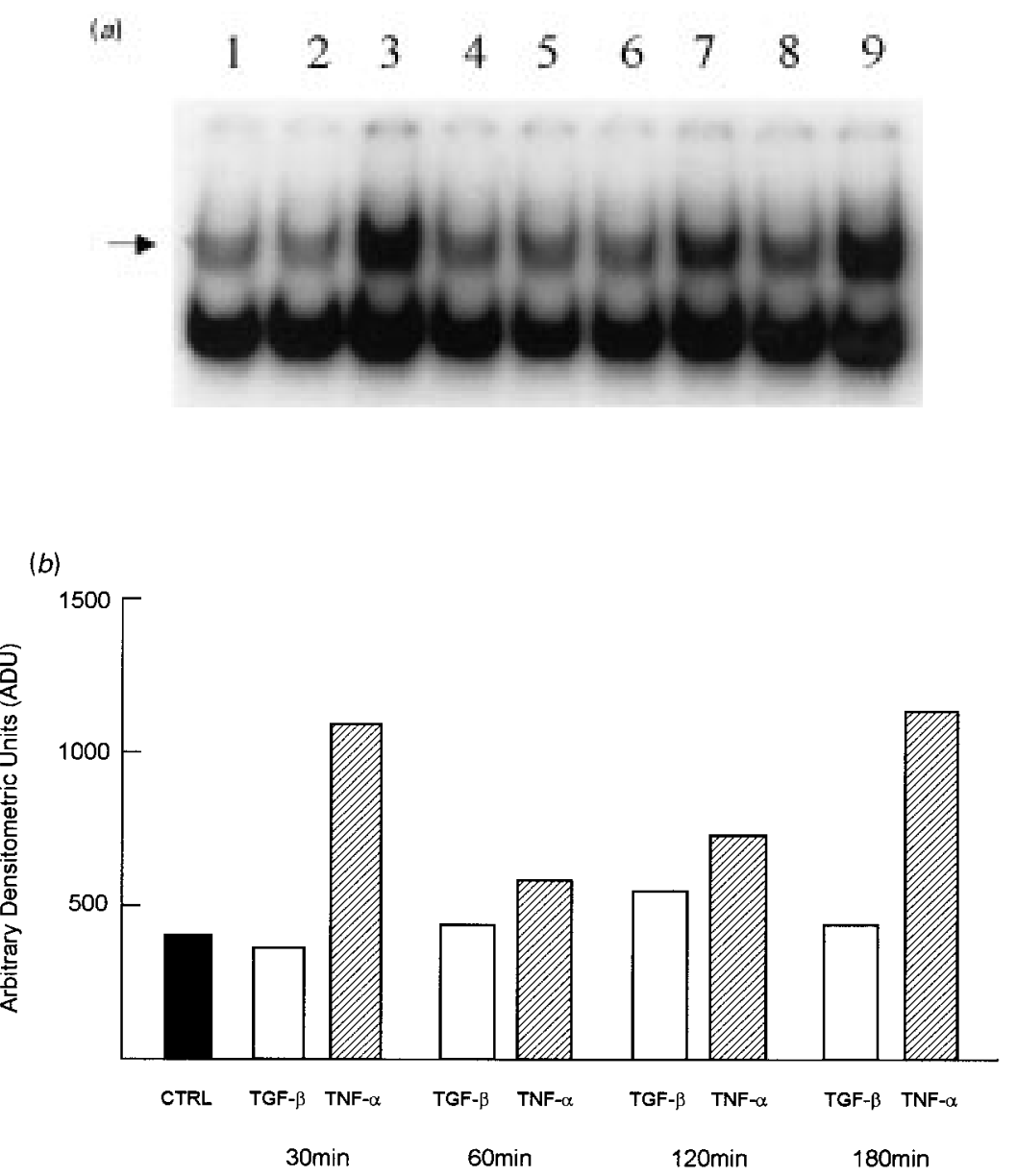

Figure 6 (a) Gel shift assay of nuclear protein extracts $(5 \mu \mathrm{g} /$ lane $)$ isolated from UT-OC-3 cells. Unstimulated cells show constitutive DNA-binding of NF- $\kappa \mathrm{B}$ and this binding activity was increased by TNF- $\alpha$. Cells were cultured in the presence or absence of TGF- $\beta 1(5 \mathrm{ng} / \mathrm{ml})$ (lane 2, $30 \mathrm{~min}$; lane 4, $60 \mathrm{~min}$; lane 6, $120 \mathrm{~min}$; lane 8, $240 \mathrm{~min}$ ) and TNF- $\alpha$ $(100 \mathrm{U} / \mathrm{ml})$ (lane 3, $30 \mathrm{~min}$; lane 5, $60 \mathrm{~min}$; lane 7, $120 \mathrm{~min}$; lane 9, $240 \mathrm{~min}$ ). Control cells were cultured in basal conditions (lane 1). After culture, nuclear proteins were extracted as described in the text. The binding reactions were performed at room temperature for $30 \mathrm{~min}$ in the presence of $\mathrm{a}^{32} \mathrm{P}$-labelled oligonucleotide specific for NF- $k \mathrm{~B}$,

whereafter the samples were analysed by PAGE. The arrow indicates transcription factor-specific bands. (b) Densitometric analyses (expressed as arbitrary densitometric units) of the effects of TGF- $\beta 1(5 \mathrm{ng} / \mathrm{ml}$; open columns) and TNF- $\alpha(100 \mathrm{U} / \mathrm{ml}$; hatched columns) showed that NF- $\kappa$ B was constitutively activated and its binding activity was further increased by TNF- $\alpha$ (one representative experiment). After culture, nuclear proteins were extracted and the binding reactions were performed at room temperature for $30 \mathrm{~min}$, whereafter the samples were analysed by PAGE. The binding reaction was carried out with a ${ }^{32} \mathrm{P}$-labelled oligonucleotide specific for $\mathrm{NF}-\kappa \mathrm{B}$. The results are shown as ADU (arbitrary densitometric units). CTRL (solid column), level of constitutive binding of NF- $\kappa$. cytokines has been studied, using a newly established ovarian cystadenocarcinoma cell line.

TNF- $\alpha$ has been shown to exert anti-proliferative effects on ovarian cancer cells by inducing cytolysis (18) and enhancing the anti-tumour activity of macrophages against malignant ovarian cells (7). TNF- $\alpha$ also has therapeutic potential in combination with IFN- $\gamma$ in experimental human ovarian cancer (19). In this study, we have shown that TNF- $\alpha$ has a clear growth inhibitory effect on UT-OC-3 ovarian carcinoma cells.

$\mathrm{NF}-\kappa \mathrm{B}$ plays an important regulatory role in the transcription of genes encoding proteins involved with immune responses and with cell growth. NF- $\kappa \mathrm{B}$ activity can be induced in a wide variety of cell types in response to treatment with such agents as TNF- $\alpha(20,21)$. The inducible NF- $\kappa \mathrm{B}$ activity is attributable to the release of cytoplasmic NF- $\kappa \mathrm{B}$ from the inhibitor, I $\kappa \mathrm{B}$. In this manner, NF- $\kappa \mathrm{B}$ can serve as an important second messenger in signal transduction $(22,23)$. The significant activation of NF- $\kappa \mathrm{B}$ by TNF- $\alpha$ suggests that this transcription factor might mediate the anti-proliferative effect in UT-OC-3 cells. TNF- $\alpha$ has been reported to inhibit cell proliferation and induce NF- $\kappa \mathrm{B}$ in human myelomonoblastic leukaemia cells (20), and we have reported similar phenomena in vulvar (unpublished data) and ovarian carcinoma cells (21). The biological effects of TNF- $\alpha$ may be attributed to its ability to induce the transcription of several genes. The induction of IL- 6 and GM-CSF genes in response to TNF- $\alpha$ is known to be mediated through NF- $\kappa \mathrm{B}(22)$.

In the present study, TGF- $\beta 1$ was a growth inhibitory factor in UT-OC-3 cells. Similar results in ovarian cancer cell lines have been obtained by Jozan et al. (17) and by Grunt et al. (24). It has also been reported that TGF- $\beta 1$ is able to induce apoptosis in epithelial ovarian carcinoma cells (25). Although TGF- $\beta_{1}$ significantly inhibited proliferation of UT-OC-3 carcinoma cells, we were unable to demonstrate that these cells undergo apoptosis in response to TGF- $\beta_{1}$. However, the possibility can not be excluded that apoptosis could have been induced in a small fraction of cells, but that this was below the detection threshold of the DNA fragmentation assay. Interestingly, we have been able to show cytokine-regulated induction of apoptosis in UT-OC-2 ovarian carcinoma cells by applying the method described in this study (unpublished observations). Programmed cell death is regulated by a number of genes, including the tumour suppressor 

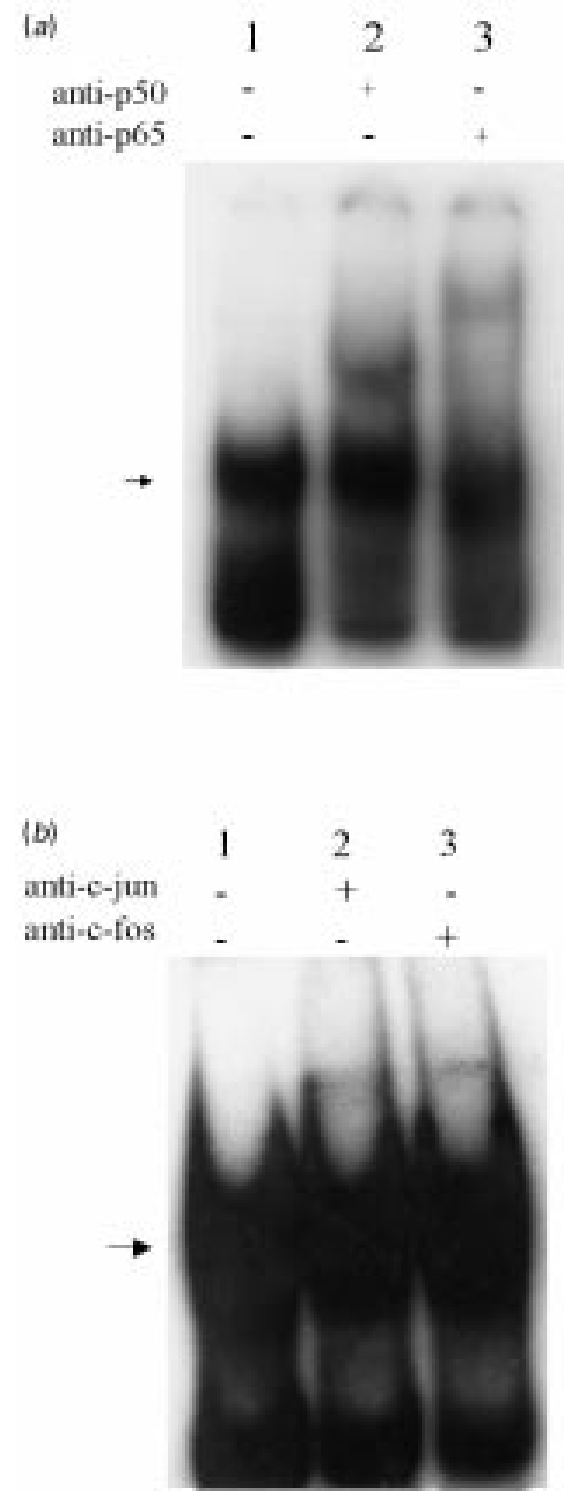

Figure 7 Molecular characterization of $(a) \mathrm{NF}-\kappa \mathrm{B}$ and $(b) \mathrm{AP}-1$ transcription factors in UT-OC-3 ovarian carcinoma cells. NF- $\kappa \mathrm{B}$ was predominantly composed of p50/p65 heterodimers and AP-1 was composed only partially of c-jun/c-fos subunits. The cells were cultured in basal culture conditions for $2 \mathrm{~h}$ whereafter nuclear proteins were isolated and preincubated in the presence $(+)$ or absence $(-)$ of transcription factor-specific antibodies (anti-p50 and anti-p65 for NF- $\kappa \mathrm{B}((\mathrm{a})$ lanes 2 and 3 respectively); anti-c-jun and anti-c-fos for AP-1 ((b) lanes 2 and 3 respectively)), followed by incubation in the presence of specific oligonucleotide and EMSA Specific binding is indicated by decreased density of the specific band in the autoradiographic analyses, together with the appearance of additional bands of greater molecular weight, probably consisting of antibody-antigen complexes. The transcription factor-specific bands not bound to antibody are indicated by arrows.

gene, p53. In some cell lines, the loss of p53 function has been associated with induction of resistance to TGF- $\beta$-induced programmed cell death $(26,27)$. It is possible that the inability of UT-OC-3 cells to undergo apoptosis may be related to the p53 status of our cell model. In fact, p53 mutations have been described recently in human ovarian (28) and other gynaecological cancers (29).

Transcription factor NF- $\kappa$ B plays a significant part in the regulation of apoptosis. According to Mayo et al. (30), the activation of NF- $\kappa \mathrm{B}$ is able to suppress a p53-independent apoptotic response. In the case of ovarian and breast cancer, NF- $\kappa \mathrm{B}$ has been found to be constitutively activated (31-33). Inhibition of NF- $\kappa \mathrm{B}$ activity in human breast cancer cell lines leads to apoptosis (33). Accordingly, the finding of constitutively active NF- $\kappa \mathrm{B}$ in ovarian carcinoma cells further suggests that this transcription factor may be associated with growth inhibitory effects and the events ultimately leading to programmed cell death.

The binding activity of AP-1 was increased after TGF- $\beta 1$ treatment in the present study. We have previously shown a similar result in endometrial and ovarian carcinoma cells (21). These findings suggest that the stimulation of AP-1 activity might be one of the mechanisms by which TGF- $\beta 1$ inhibits the growth of both ovarian and endometrial carcinoma cells. In fact, AP-1 is believed to play a central role in the control of the proliferation of many different kinds of cells (34). In addition, it has been found to be involved in the autoinduction of TGF- $\beta 1$ (35). Furthermore, there is evidence of an association between the anti-mitogenic action of TNF- $\alpha$ and AP-1 (36). In the present study, growth-inhibitory TNF- $\alpha$ was also able to increase the binding activity of AP-1.

Both in vitro and in vivo studies have shown that human ovarian cancer is sensitive to the antiproliferative effects of recombinant human IFN- $\alpha$ and IFN- $\gamma(19,37,38)$. Similarly, the results of this study indicate that both IFNs inhibit the proliferation of UT-OC-3 ovarian carcinoma cells in vitro. It has been observed that, under appropriate conditions, the anticancer activity of IFNs is mediated by cytolysis in ovarian and cervical cancer cells (37-39). We have also previously found that both IFNs are growth inhibitory in endometrial carcinoma cells (21), and that IFN- $\gamma$ exerts a growth inhibitory effect on vulvar carcinoma cells (40). All these findings indicate that IFNs are able to inhibit the proliferative activity of several types of neoplastic cells originating from female reproductive organs.

In the present study, the cytokines were tested only as single agents. However, it has been shown that, for example, IFN- $\gamma$ is able to enhance the anti-proliferative effect of TNF- $\alpha$ in cervical carcinoma cells (41), and that the combination therapy of TNF- $\alpha$ and IFN- $\gamma$ used together significantly inhibits ovarian cancer cell growth (19). Interestingly, in colorectal carcinoma cells, the initiation of apoptosis was achieved by the combination of TNF- $\alpha$ and IFN- $\gamma$ (42). In contrast to these studies, the combination of IFN- $\gamma$ and TNF- $\alpha$ produced no further growth inhibitory response 
compared with immunomodulatory factors used alone in lung carcinoma cell models (43). It would be very interesting to test different combinations of cytokines in UT-OC-3 ovarian carcinoma cells.

A growth inhibitory effect of GM-CSF on human ovarian carcinoma cells was observed in the present study. This result is in accordance with those reported by Salmon \& Liu (44). In addition, we have previously found that DNA synthesis was inhibited by GM-CSF in endometrial (21) and vulvar (40) carcinoma cells. It has also been observed that irradiated tumour cells secreting GM-CSF show specific anti-tumour immunity in a number of tumour models (45). In contrast to the growth inhibitory effects observed in the present studies, GM-CSF has been believed to have only a modest (if any) growth modulatory effect on most nonhaematopoietic neoplasms (39). In clinical practice, at present, the primary indication for GM-CSF treatment of patients with malignant disease is to improve the recovery of the bone marrow after chemotherapyinduced myelosuppression (46).

In the present study, the effect of IL-6 on DNA synthesis was found to be highly time-dependent and observed only after $48 \mathrm{~h}$ of exposure. Anti-tumour effects of IL- 6 against sarcoma and adenocarcinoma of the colon have been demonstrated in vivo (47), and Chen et al. (48) have observed that IL-6 inhibits the growth of human breast and ovarian carcinoma cells in vitro. However, IL-6 has also been reported to stimulate the growth of ovarian carcinoma cells in vitro (46). It seems likely that IL-6 is able either to inhibit or to stimulate cell growth, depending on the cell type used and the different culture conditions.

In summary, our results indicate that IFN- $\alpha$, IFN- $\gamma$, TGF- $\beta 1$, TNF- $\alpha$, IL- 6 and GM-CSF have a growth inhibitory effect on UT-OC-3 ovarian carcinoma cells. Transcription factors $\mathrm{AP}-1$ and $\mathrm{NF}-\kappa \mathrm{B}$ may be involved in mediating these growth-inhibitory effects of cytokines. Programmed cell death could not be demonstrated after exposure to these cytokines, but constitutive active $\mathrm{NF}-\kappa \mathrm{B}$ might protect cells from induction of apoptosis by cytokines. Further studies of cytokine-mediated growth inhibition and the role of transcription factors $\mathrm{AP}-1$ and NF- $\kappa \mathrm{B}$ in the regulation of cell growth in ovarian cancer cells are needed.

\section{Acknowledgements}

We thank Nina Lahdenpohja for technical assistance. This project was supported by grants from The Research Fund of Tampere University Hospital, Ida Montini Foundation, Pirkanmaa Cancer Society and the Finnish Culture Foundation.

\section{References}

1 Fathalla M. Incessant ovulation - a factor in ovarian neoplasia? Lancet 19712163.
2 Schildkraut J, Bastos E \& Berchuck A. Relationship between lifetime ovulatory cycles and overexpression of mutant p53 in epithelial ovarian cancer. Journal of the National Cancer Institute 199789 932-938.

3 Serov S, Scully R \& Sobin L. International Classification of Tumours no 9. Histological Typing of Ovarian Tumours. Geneva: World Health Organization, 1973.

4 Merino M \& Jaffe G. Age contrast in ovarian pathology. Cancer $199371537-544$.

5 Itri L. The interferons. Cancer $199270940-945$.

6 Miller A, McBride W, Hunt K \& Economou J. Cytokine-mediated gene therapy for cancer. Annals of Surgical Oncology 19941 436-450.

7 Richters C, Burger C, van de Loosdrecht A, van Rijswijk R, Calame W, Bleker $\mathrm{O}$ et al. The cellular composition in the peritoneal cavity and the cytotoxic function of the peritoneal cells from patients with ovarian cancer; effect of tumour necrosis factor- $\alpha$ treatment. Cancer Letters 199368 25-31.

8 Tabibzadeh S. Cytokines and the hypothalamic-pituitaryovarian-endometrial axis. Human Reproduction Update 19949 947-967.

9 Erroi A, Sironi M, Chiaffarino F, Zhen-Guo C, Mengozzi M \& Mantovani A. IL-1 and IL-6 release by tumor-associated macrophages from human ovarian carcinoma. International Journal of Cancer 198944 795-801.

10 Moradi M, Carson L, Weinberg B, Haney A, Twiggs L \& Ramakrishnan S. Serum and ascitic fluid levels of interleukin-1, interleukin-6, and tumor necrosis factor-alpha in patients with ovarian epithelial cancer. Cancer 199372 2433-2440.

11 Pisa P, Halapi E, Pisa E, Gerdin E, Hising C, Buchta A et al. Selective expression of interleukin 10, interferon $\gamma$, and granulocyte-macrophage colony-stimulating factor in ovarian cancer biopsies. Proceedings of the National Academy of Sciences of the USA $1992897708-7712$.

12 Engblom P, Rantanen V, Kulmala J, Helenius H \& Grenman S. Additive and supra-additive cytotoxicity of cisplatin-taxane combinations in ovarian carcinoma cell lines. British Journal of Cancer 199979 286-292.

13 Grenman S, Engblom P, Rantanen V, Klemi P \& Isola J. Cytogenetic characterization of five new ovarian carcinoma cell lines. Acta Obstetrica et Gynecologica Scandinavica 19977644.

14 Asantila T \& Toivanen P. Potentiation by fluorodeoxyuridine of ${ }^{125}$ I-deoxyuridine uptake by human and chicken lymphocytes in the quantitation of mitogenic response. Journal of Immunological Methods $1974673-82$.

15 Smith C \& Williams G. Antibodies to CD3/T-cell receptor complex induce death by apoptosis in immature T cells in thymic cultures. Nature $1989337181-184$.

16 Andrews N \& Faller D. A rapid micropreparation technique for extraction of DNA-binding proteins from limiting numbers of mammalian cells. Nucleic Acids Research 199119249.

17 Jozan S, Guerrin M, Mazars P, Dutaur M, Monsarrat B, Cheutin F et al. Transforming growth factor $\beta_{1}\left(\mathrm{TGF}-\beta_{1}\right)$ inhibits growth of a human ovarian carcinoma cell line (OVCCR 1 ) and is expressed in human ovarian tumors. International Journal of Cancer 199252 766-770.

18 Kost E, Herzog T, Adler L, Williams S \& Mutch D. The role of tumor necrosis factor receptors in tumor necrosis factor- $\alpha$ mediated cytolysis of ovarian cancer cell lines. American Journal of Obstetrics and Gynecology 1996 174 145-153.

19 Balkwill F, Ward B, Moodie E \& Fiers W. Therapeutic potential of tumor necrosis factor- $\alpha$ and $\gamma$-interferon in experimental human ovarian cancer. Cancer Research 198747 4755-4758.

20 Chaturvedi M, LaPushin R \& Aggarwal B. Tumor necrosis factor and lymphotoxin. Journal of Biological Chemistry 1994269 14575-14583.

21 Seppänen M, Henttinen T, Lin L, Punnonen J, Grenman S, Punnonen R et al. Inhibitory effect of cytokines on ovarian and endometrial carcinoma cells in vitro with special reference to 
induction of specific transcriptional regulators. Oncology Research 199810 575-589.

22 Baldwin A. The NF- $\kappa \mathrm{B}$ and $\mathrm{I} \kappa \mathrm{B}$ proteins: new discoveries and insights. Annual Review of Immunology 199614 649-681.

23 Grimm S \& Bauerle P. The inducible transcription factor NF- $\kappa$ B: structure-function relationship of protein subunits. Biochemical Journal $1993290297-308$.

24 Grunt T, Somay C, Ellinger A, Pavelka M, Dittrich E \& Dittrich C. The differential effects of N,N-dimethylformamide and transforming growth factor- $\beta_{1}$ on a human ovarian cancer cell line (HOC-7). Journal of Cellular Physiology 1992151 13-22.

25 Mathieu C, Jozan S, Mazars P, Come M, Moisand A \& Valette A. Density-dependent induction of apoptosis by transforming growth factor- $\beta_{1}$ in a human ovarian carcinoma cell line. Experimental Cell Research $199521613-20$.

26 Zhu Y-M, Bradbury D \& Russell N. Wild-type p53 is required for apoptosis induced by growth factor deprivation in factordependent leukaemic cells. British Journal of Cancer 199469 468-472.

27 Eliopoulos A, Kerr D, Herod J, Hodkings L, Krajewski S, Reed J et al. The control of apoptosis and drug resistance in ovarian cancer: influence of p53 and Bcl-2. Oncogene 199511 12171228

28 Provencher D, Lounis H, Fink D, Drouin P \& Mes-Masson A. Discordance in p53 mutations when comparing ascites and solid tumors from patients with serous ovarian cancer. Tumour Biology 199718 167-174.

29 Rantanen V, Grenman S, Kurvinen K, Hietanen S, Raitanen M \& Syrjänen S. p53 mutations and presence of HPV DNA do not correlate with radiosensitivity of gynecological cancer cell lines. Gynecologic Oncology $199871352-358$.

30 Mayo M, Wang C, Cogswell P, Rogers-Graham K, Lowe S, Der C et al. Requirement of NF- $\kappa \mathrm{B}$ activation to suppress p53independent apoptosis induced by oncogenic Ras. Science 1997 278 1812-1815.

31 Bours V, Dejardin E, Goujon-Letawe F, Merville M \& Castronovo V. The NF- $\kappa$ B transcription factor and cancer: high expression of $\mathrm{NF}-\kappa \mathrm{B}$ and $\mathrm{I} \kappa \mathrm{B}-$ related proteins in tumor cell lines. Biochemical Pharmacology 199447 145-149.

32 Nakshatri H, Bhat-Nakshatri P, Martin D, Goulet R Jr \& Sledge G Jr. Constitutive activation of NF- $\kappa \mathrm{B}$ during progression of breast cancer to hormone-independent growth. Molecular and Cellular Biology 199717 3629-3639.

33 Sovak M, Bellas R, Kim D, Zanieski G, Rogers A, Traish A et al. Aberrant nuclear factor- $\kappa \mathrm{B} /$ Rel expression and the pathogenesis of breast cancer. Journal of Clinical Investigations 1997100 2952-2960.

34 Angel P \& Karin M. The role of Jun, Fos and the AP-1 complex in cell-proliferation and transformation. Biochimica et Biophysica Acta 19911072 129-157.

35 Kim S, Angel P, Lafyatis R, Hattori K, Kim K, Sporn M et al. Autoinduction of transforming growth factor $\beta_{1}$ is mediated by the AP-1 complex. Molecular and Cellular Biology 199010 1492-1497.

36 Dixit V, Marks R, Sarma V \& Prochowniks E. The antimitogenic action of tumor necrosis factor is associated with increased
AP-1/c-jun proto-oncogene transcription. Journal of Biological Chemistry 1989264 16905-16909.

37 Powell C, Horuchi T, Kao M-S \& Collins J. Interferon alfa activates a lytic mechanism in ovarian and cervical carcinoma cells. American Journal of Obstetrics and Gynecology 1993169 661-667.

38 Welander $\mathrm{C}$. Use of interferon in the treatment of ovarian cancer as a single agent and in combination with cytotoxic drugs. Cancer $198759617-619$.

39 Massad L, Powell C, Kao M-S \& Collins J. Expression of a resistance in ovarian and cervical carcinoma cells prevents their lysis by $\gamma$-interferon. Cancer Research 199050 4923-4928.

40 Vihko KK, Seppänen M, Henttinen T, Punnonen J, Grenman S \& Punnonen R. Regulation of UM-SCV-1A and UM-SCV-6 vulvar carcinoma cell proliferation by cytokines. Cancer Immunology Immunotherapy 199743 368-374.

41 Lewis G, Aggarwal B, Eessalu T, Sugarman B \& Shepard M. Modulation of the growth of transformed cells by human tumor necrosis factor- $\alpha$ and interferon- $\gamma$. Cancer Research 198747 $5382-5385$

42 Wright K, Kolios G, Westwick J \& Ward S. Cytokines-induced apoptosis in epithelial HT-29 cells is dependent on nitric oxide formation. Evidence for an interleukin-13-driven phosphatidylinositol 3-kinase-dependent survival mechanism. Journal of Biological Chemistry 1999274 17193-17201.

43 Suarez-Pestana E, Bjoklund G, Larsson R, Nygren P, Nilsson K \& Bergh J. Effects of interferons and tumour necrosis factor-alpha on human lung cancer cell lines and the development of an interferon-resistant lung cancer cell line. Acta Oncologica 199635 473-478.

44 Salmon S \& Liu R. Effects of granulocyte-macrophage colonystimulating factor on in vitro growth of human solid tumors. Journal of Clinical Oncology 19897 1346-1350.

45 Dranoff G, Jaffee E, Lazemby A, Golumbek P, Levitsky H, Brose K et al. Vaccination with irradiated tumor cells engineered to secrete murine granulocyte-macrophage colony-stimulating factor stimulates potent, specific, and long-lasting anti-tumor immunity. Proceedings of the National Academy of Sciences of the USA $1993903539-3543$.

46 Steward W. Granulocyte and granulocyte-macrophage colonystimulating factors. Lancet 1993342 153-157.

47 Mule J, McIntosh J, Jablons D \& Rosenberg S. Antitumor activity of recombinant interleukin 6 in mice. Journal of Experimental Medicine 1990171 629-636.

48 Chen L, Shulman L \& Revel M. IL-6 receptors and sensitivity to growth inhibition by IL-6 in clones of human breast carcinoma cells. Journal of Biological Regulators and Homeostatic Agents 1991 5 125-136.

49 Wu S, Rodabaugh K, Martinez-Maza O, Watson J, Silberstein D, Boyer $\mathrm{C}$ et al. Stimulation of ovarian tumor cell proliferation with monocyte products including interleukin-1, interleukin-6, and tumor necrosis factor- $\alpha$. American Journal of Obstetrics and Gynecology 1992166 997-1007.

Received 27 July 1999

Accepted 13 December 1999 